\title{
Regional and semi-regional modelling of wide-angle shear waves in OBS data from the Vøring Basin, N. Norway-a comparison
}

\author{
Per Digranes $^{1 *}$, Rolf Mjelde ${ }^{1,2}$, Shuichi Kodaira ${ }^{1 * *}$, Hideki Shimamura $^{3}$, Toshihiko Kanazawa ${ }^{2}$, and Hajime Shiobara ${ }^{2,3}$ \\ ${ }^{1}$ Institute of Solid Earth Physics, Univ. of Bergen, Allegt. 41, 5007 Bergen, Norway \\ ${ }^{2}$ Earthquake Research Institute, Tokyo Univ., Yayoi 1-1-1, Bunkyo-ku, Tokyo 113-0032, Japan \\ ${ }^{3}$ Institute for Seismology and Volcanology, Hokkaido Univ., N10W8 Kita-ku, Sapporo 060, Japan
}

(Received February 21, 2002; Revised September 18, 2002; Accepted January 28, 2003)

\begin{abstract}
Shear wave refractions and wide-angle reflections recorded on densely spaced Ocean Bottom Seismometers (OBSs) in the Vøring Basin have been modelled by use of 2-D kinematic ray-tracing. Twenty-five three component OBSs were deployed along a $120 \mathrm{~km}$ long profile, and the semi-regional shear-wave velocity model derived from modelling the horizontal components is compared with a regional model from 5 OBSs along the same profile. The overall shear-wave velocity distribution of the two models are fairly similar, proving that the regional procedure with large OBS spacing provides a reliable regional shear-wave velocity model. The semi-regional model is more detailed than the regional model due to the much closer receiver spacing. The vertical resolution is improved, especially in the shallow sediments, and this enables a more detailed lithological interpretation to be carried out. Intermediate and deep sediments are also better resolved in the semi-regional model, indicating both vertical and lateral changes in the lithology. The $V_{p} / V_{s}$ ratio inferred for the crystalline basement is 1.75 in both models, considered to be typical for the continental crust. An increase in the $V_{p} / V_{s}$ ratio in the lower crust is observed both in the regional and in the semi-regional model. This indicates a more mafic composition in the lower crust, supporting the interpretation that the lower crust is a "mixing" of continental crust and magmatic underplating.
\end{abstract}

\section{Introduction}

Ocean Bottom Seismometers (OBS) have traditionally been used in scientific investigations of the lithosphere, and it is well documented that wide-angle reflections and refractions recorded on OBSs generally provide a better image of the crustal structure than (near vertical incidence) multichannel reflection profiles alone (e.g. Morgan et al., 1989; Todd and Reid, 1989; Holbrook et al., 1994). However, during the last decade several OBS wide-angle surveys have been performed on a more local scale to complement reflection seismic data in areas with a high hydrocarbon potential (e.g. Mjelde et al., 1996a; Samson et al., 1995). The OBS wideangle method is particularly important on volcanic margins, where the multichannel reflection technique is ineffective in many areas (e.g. Mjelde et al., 1997a). One such area is the Vøring Basin, situated on the outer Norwegian continental margin (Fig. 1). The Vøring Basin is characterised by sill intrusions in the sediments, obscuring arrivals from deeper levels (e.g. Skogseid et al., 1992). However, clear P to S converted waves are often observed in seismic data from these areas, as conversions from compressional- to shear waves are favoured by the high velocity sill intrusions (Mjelde and Sellevoll, 1993; Digranes et al., 1996, 1998).

\footnotetext{
${ }^{*}$ Statoil, Bergen, Norway.

** Jamstec, Yokosuka, Japan.
}

Copy right (C) The Society of Geomagnetism and Earth, Planetary and Space Sciences (SGEPSS); The Seismological Society of Japan; The Volcanological Society of Japan; The Geodetic Society of Japan; The Japanese Society for Planetary Sciences.
As part of an extensive OBS survey in the central and northern part of the Vøring Basin in 1992 twenty-five OBSs were deployed along a $120 \mathrm{~km}$ long profile with $1.5-8.0$ $\mathrm{km}$ between the OBSs (Fig. 2). The main objective of this semi-regional experiment was to investigate to what extent the dense OBS sampling would provide better estimates on the P- and shear-wave velocities in the shallow sediments, as well as the distribution of igneous sills and deeper sedimentary and crystalline structures, than the regional procedure. The 2-D ray-tracing modelling of the $\mathrm{P}$-wave data from the semi-regional experiment was described by Mjelde et al. (1997b). This paper describes the 2-D ray-tracing modelling of the shear waves from the semi-regional experiment, and compares the regional- and semi-regional models.

\section{Geological Framework}

The Vøring margin, situated between the Møre and Lofoten Margins off Mid Norway (Fig. 1), has been dominated by extensional tectonics since Devonian time (Larsen et al., 1989; Surlyk et al., 1984). The margin has been studied by use of seismic reflection and refraction data (Bøen et al., 1984; Eldholm and Mutter, 1986; Mutter et al., 1984, 1988; Skogseid and Eldholm, 1989; Mjelde et al., 1997a, 1998, 2001; Berndt et al., 2000; Raum et al., 2002), as well as commercial drilling on the continental shelf (Spencer et al., 1984, 1986; Dalland et al., 1988) and scientific drilling at the Vøring Plateau (Talwani et al., 1976; Eldholm et al., 1987, 1989).

The Vøring Basin is a large sedimentary basin, with a min- 


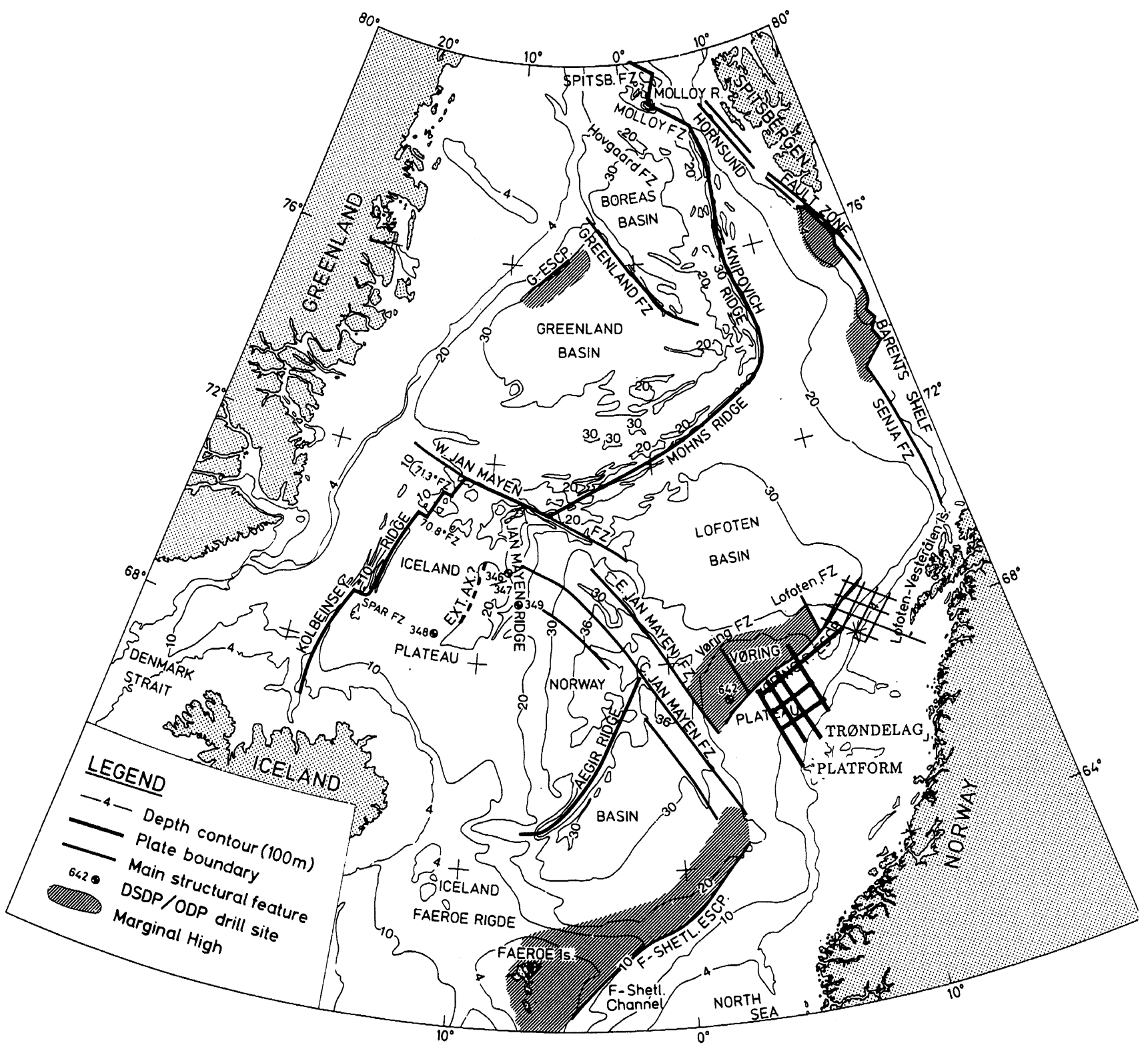

Fig. 1. Regional physiography and structural features of the ocean basin and continental margins in the Norwegian-Greenland Sea. The marginal highs represents part of the North Atlantic Volcanic Province. The investigated area in the Vøring Basin is indicated with bold lines, and older OBS-profiles further north are shown with thin lines. Modified from Eldholm et al. (1990).

imum of $3 \mathrm{~km}$ of pre-Cretaceous sedimentary strata inferred regionally (Bøen et al., 1984; Skogseid and Eldholm, 1989), while as much as $10 \mathrm{~km}$ of sedimentary rocks may exist locally (Eldholm and Mutter, 1986; Planke et al., 1991). The seaward limit of the Vøring Basin (the Vøring Escarpment, Fig. 2) is presently observed below $\approx 2 \mathrm{~km}$ of post opening sediments. The late syn-rift period was associated with high magmatic activity, and massive emplacement of magmatic rocks. These rocks were partially extruded on the surface as flood-basalts extending 10-40 km landward of the Vøring Escarpment, and partially intruded as sills into the sediments at intermediate and deep levels in the Vøring Basin (Skogseid and Eldholm, 1989). Magmatic material was further emplaced as thick magmatic intrusions into the lower crust at both sides of the Vøring Escarpment (Skogseid et al., 1992).

\section{Data Acquisition and Processing}

The location of the semi-regional and regional lines and OBSs from the 1992 survey is shown in Fig. 2, and a detailed description of the experiment is given in Mjelde $e t$ al. (1993, 1996a). In the semi-regional experiment along profile 7 the OBS-spacing varies between $1.5-8 \mathrm{~km}$, according to the geological complexity along the profile (Mjelde et al., 1997b).

The analogue OBSs used are developed at the Institute for Seismology and Volcanology, Hokkaido University; and at the Earthquake Research Institute, Tokyo University (Asada et al., 1979; Yamada et al., 1981; Kanazawa, 1986; Shimamura, 1988; Kanazawa, 1993). The OBSs have three orthogonal $4.5 \mathrm{~Hz}$ geophones which are gimbal mounted, and the analogue recording unit can register continuously for 14 days within the $1-30 \mathrm{~Hz}$ frequency range. 


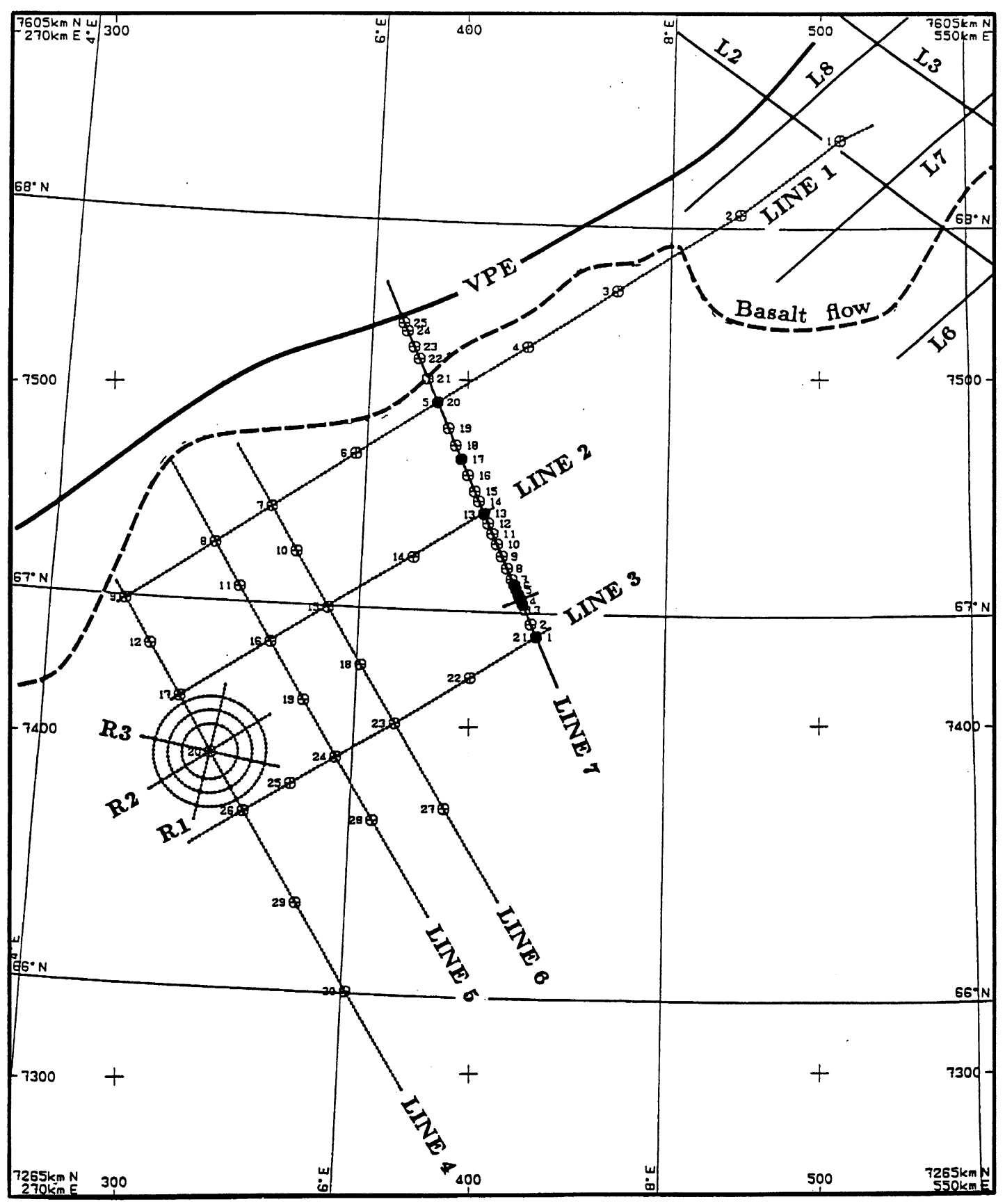

Fig. 2. The survey area with the semi-regional and regional profiles indicated. VPE = Vøring Plateau Escarpment.

In both the regional and semi-regional experiment a lowfrequency airgun source with a total volume of $4800 \mathrm{cu}$. in. (78.7 1) was used, with a shot interval of $\approx 250 \mathrm{~m}$. The analogue OBS-data have been digitized at the University of Hokkaido, Japan, and further signal processing has been performed at the Institute of Solid Earth Physics (IFJ), University of Bergen.

An example of the raw data is shown in Fig. 3. The data are contaminated by low frequency noise, and a $5-12 \mathrm{~Hz}$ band-pass filter was applied to all three components. The seismic pulse from the low-frequency source has prominent bubble oscillations with a primary/bubble ratio of 1.4 , which gives the raw data a 'ringy' appearance. Deconvolution filters were tested to attenuate the 'ringing', and a predictive deconvolution with a $32 \mathrm{~ms}$ gap, $250 \mathrm{~ms}$ operatorlength and $3000 \mathrm{~ms}$ design window gave a good result (Fig. 4).

F-k filtering and trace-mixing were tested to enhance the quality of the shear waves on the horizontal components. However, due to the coarse spatial sampling $(\approx 250 \mathrm{~m})$ the multichannel processing did not improve the data, and the processing was restricted to frequency filtering and deconvolution only. The X-T data are displayed with travel-times reduced by $8 \mathrm{~km} / \mathrm{s}$.

\section{Mode Conversion and Identification of Shear Waves}

Seismic investigations using a source situated in the water layer rely on mode conversion to generate shear waves. 


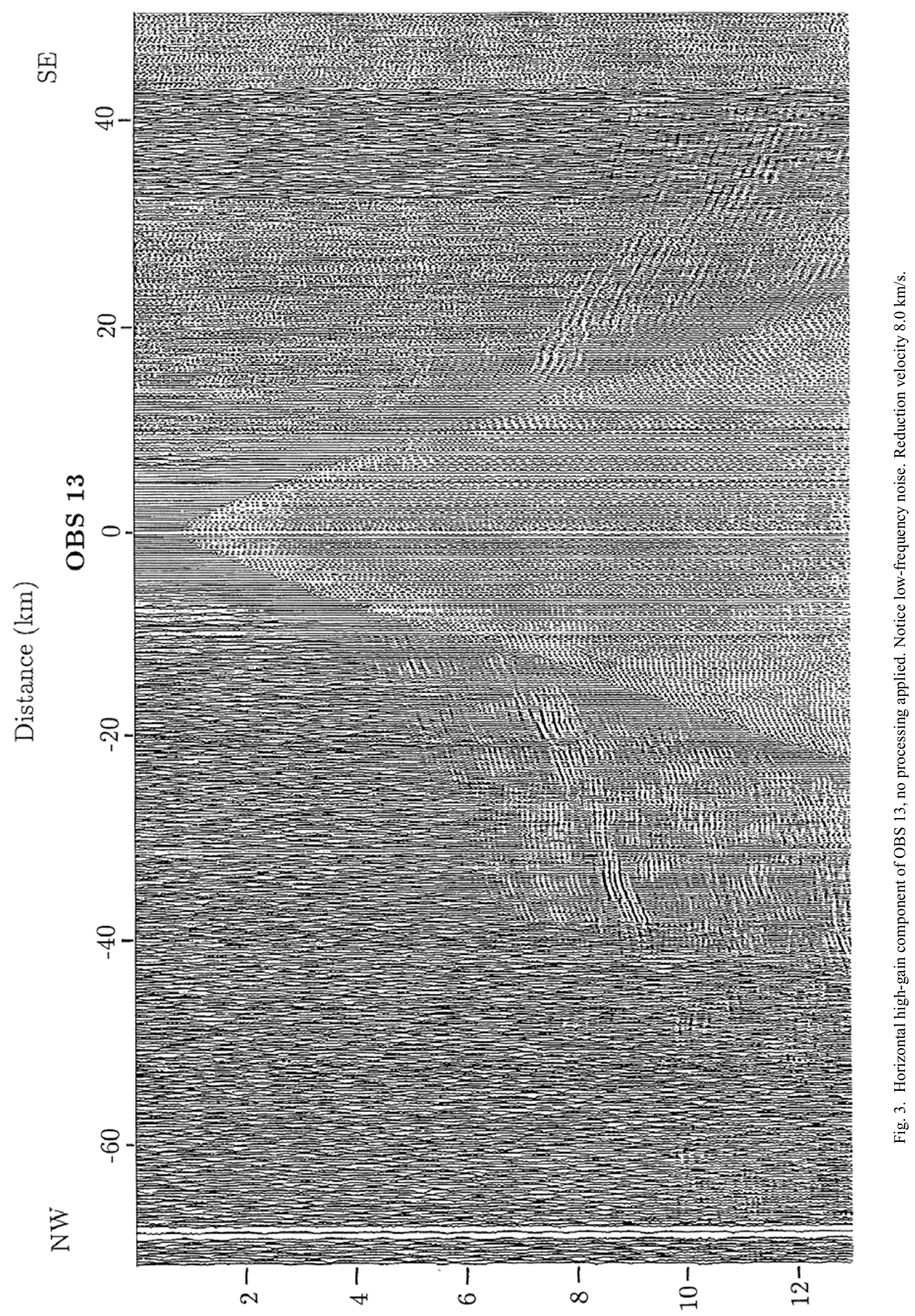

(วəs) 8/đ-エ 


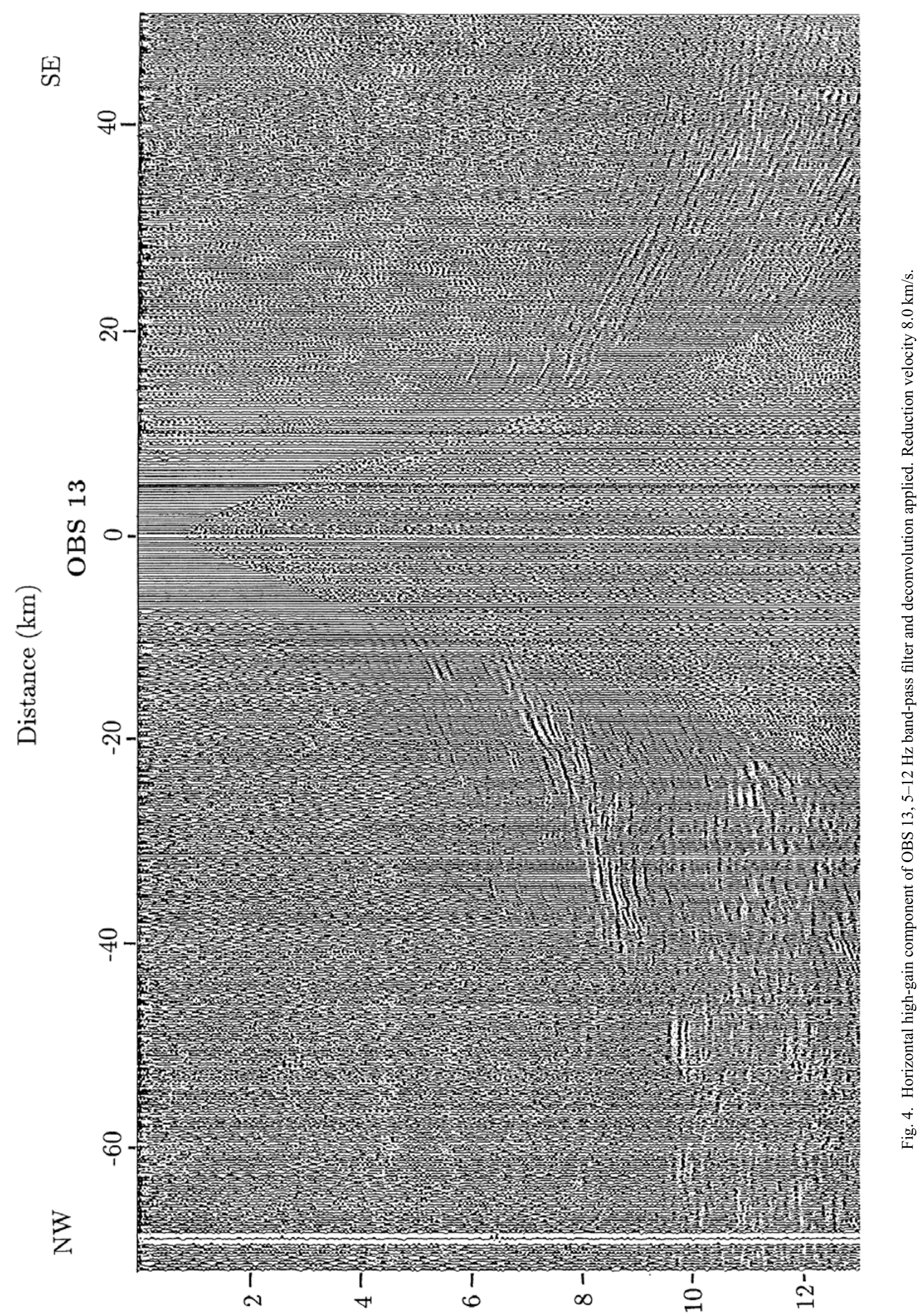

(әәs) $8 /$ đ-I 
The amount of energy converted from P- to shear waves depend on the incidence angle and the contrast in $\mathrm{P}$ and $\mathrm{S}$ velocities and density across the interface. The most efficient mode conversion occurs where the seismic wave encounters a large change in seismic velocitiy over a distance of less than half a wavelength (White and Stephen, 1980). Hence, a hard water bottom will act as an efficient conversion interface (e.g. Tatham and Goolsbee, 1984; Kennett, 1996). However, in many marine environments the water bottom material consists of poorly consolidated sediments, with shear-wave velocities much lower than the P-wave velocity in water. Observations of very high $V_{p} / V_{s}$ ratios (7.0 9.2) in shallow marine sediments have been related to a low degree of compaction (e.g. Chung et al., 1990; Bromirski et al., 1992), and Hamilton (1976) suggested that the poorly consolidated bottom sediments in some areas consist of a transition zone in which $\mathrm{V}_{s}$ may be much lower than 150 $\mathrm{m} / \mathrm{s}$ at the water bottom, rapidly increasing with depth. For the frequencies of interest, such a transition zone might be several wavelengths long, and theoretical calculations show that the conversion efficiency in the 10 to $100 \mathrm{~Hz}$ range is extremely low (Kim and Seriff, 1992). Thus, a soft seabed with a gradient in the sediment properties beneath is a poor conversion interface, while mode conversion might be quite efficient at a hard seabed, especially for wide angle propagation. In Fig. 5(a) the theoretical partitioning of energy into different wave modes is shown for a P-wave incident at the seabed, with a relatively high water bottom shear-wave velocity $\left(\mathrm{V}_{S}\right)$ of $760 \mathrm{~m} / \mathrm{s}$. The conversion from $\mathrm{P}$ - to shear-waves becomes more efficient as the angle of incidence increases, and at angles of incidence larger than the P-wave critical angle mode conversion becomes quite significant.

We do not have any detailed information on the composition of the water-bottom sediments along profile 7 . The Pwave water-bottom velocities derived from reflection seismic data varies from $1400 \mathrm{~m} / \mathrm{s}$ in the NW part to $1900 \mathrm{~m} / \mathrm{s}$ in the SE part of the profile, indicating a relatively soft to medium hard seabottom. However, these velocities represent average values in the layer beneath the seabed, and significantly lower velocities might be expected in the uppermost interval. The modelling of the shear waves implies that the conversion efficiency in the sea bottom is low, as most conversions are modelled to occur at the reflecting/refracting interfaces as PS or PPS waves (Digranes et al., 1998).

The tops of the high velocity igneous sill intrusions are mapped as efficient conversion interfaces (Digranes et al., 1996, 1998). The conversion efficiency is particularly high for angles of incidence above the P-wave critical angle (Fig. 5(b)), and we observe clear P- to S converted waves at offsets from 5-120 km (Figs. 6-10) in the wide-angle OBS data. Figure 5(c) shows the theoretical partitioning of energy into different wave modes for a shear wave incident at a sediment-sill intrusion interface. In this example one should note that most of the incident energy is transmitted as shear waves for angles of incidence below $30^{\circ}$, while total reflection occur at angles of incidence above the shear-wave critical angle. Only a small amount of the incident energy is converted to P-waves. Considering the different raypaths of the PS/PPS waves (conversion at the reflecting/refracting interface) and the SS/SSS waves (conversion at the sea bot- a.

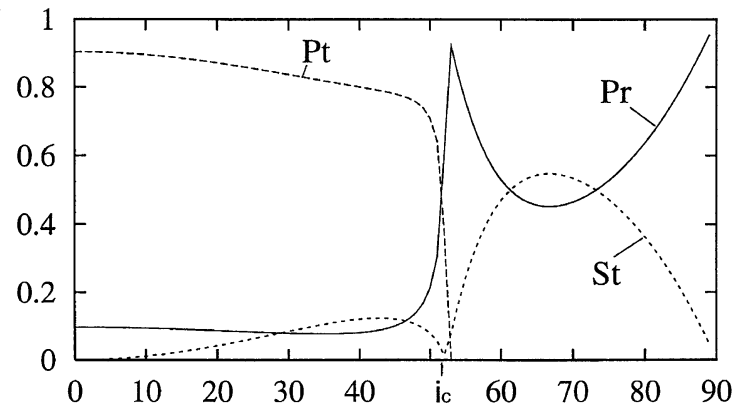

b.

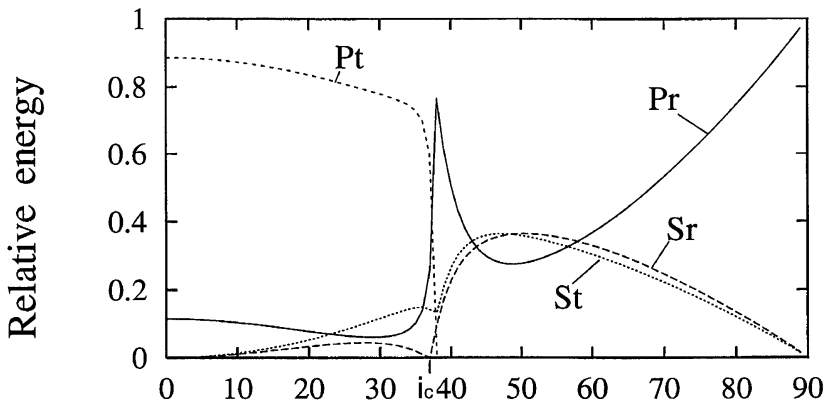

c.

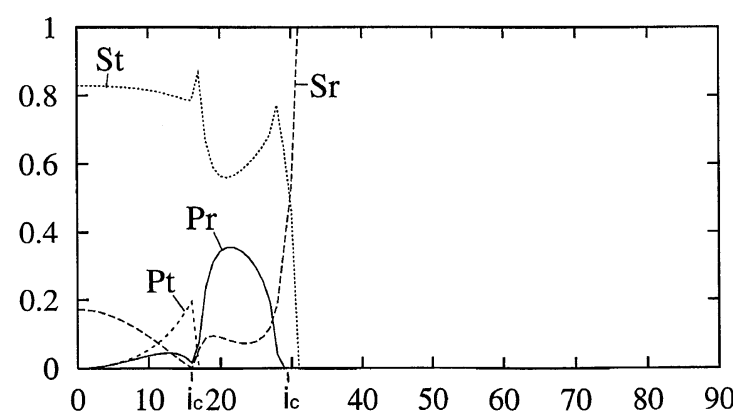

Incidence angle (deg.)

Fig. 5. Theoretical partitioning of energy for (a) a P-wave incident at the seafloor $\left(V p_{1}=1.5 \mathrm{~km} / \mathrm{s}, \rho_{1}=1.0, V p_{2}=1.9 \mathrm{~km} / \mathrm{s}, V s_{2}=0.76\right.$ $\mathrm{km} / \mathrm{s}, \rho_{2}=1.5$ ), for (b) a P-wave incident at a sediment $/$ sill interface $\left(V p_{1}=3.2 \mathrm{~km} / \mathrm{s}, V s_{1}=1.52 \mathrm{~km} / \mathrm{s}, \rho_{1}=2.2, V p_{2}=5.2 \mathrm{~km} / \mathrm{s}\right.$, $V s_{2}=2.98 \mathrm{~km} / \mathrm{s}, \rho_{2}=2.7$ ), and (c) for a shear wave incident at a sediment sill interface $\left(V p_{1}=3.2 \mathrm{~km} / \mathrm{s}, V s_{1}=1.52 \mathrm{~km} / \mathrm{s}, \rho_{1}=2.2\right.$, $\left.V p_{2}=5.2 \mathrm{~km} / \mathrm{s}, V s_{2}=2.98 \mathrm{~km} / \mathrm{s}, \rho_{2}=2.7\right) . \mathrm{Pr}, \mathrm{Pt}, \mathrm{Sr}$ and $\mathrm{St}$ refer to reflected P-energy, transmitted P-energy, reflected S-energy and transmitted S-energy, respectively. $I_{c}=$ critical angle.

tom) it is more likely to observe the PS/PPS waves at large offsets, which is consistent with the modelling results. Most shear-wave arrivals are modelled involving only one mode conversion along the raypath, as multiple converted waves are less likely to be observed in the data.

In Fig. 6 the vertical and one horizontal component from one OBS is shown. The similar reflection/refraction pattern observed on the two components is a distinctive feature of the Vøring OBS data. The later arrival times on the horizontal components indicate that these waves mainly represent refracted compressional-waves, having travelled partly as shear waves, or P- to $\mathrm{S}$ wide angle reflections. The OBS data is recorded on three component gimballed geophones, hence plots of the particle motions around the first onset of the different wave modes are utilized to verify the identification of the different phases. The compressional- and shear- 

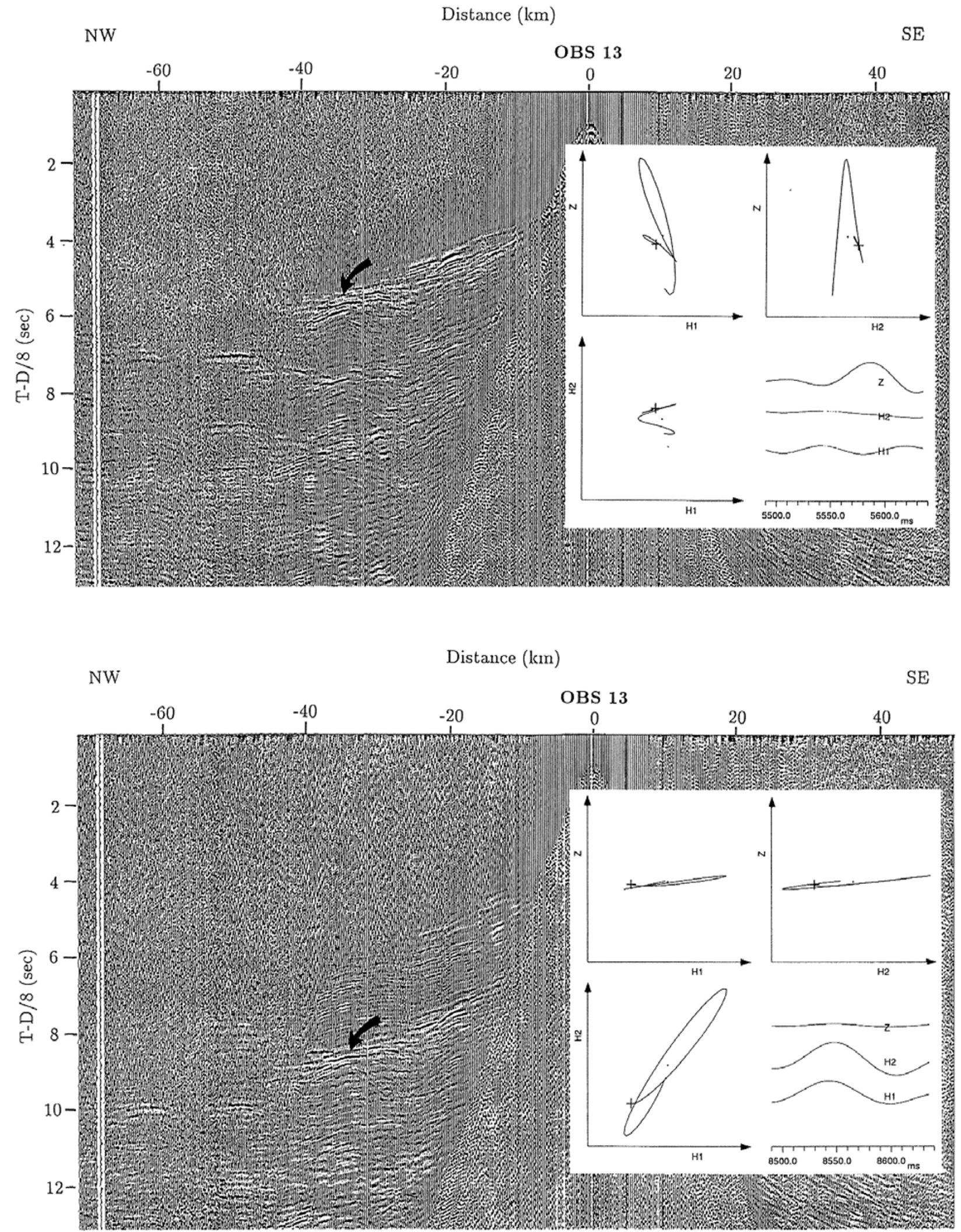

Fig. 6. Vertical (upper) and horizontal (lower) high-gain component of OBS 13,5-12 Hz band-pass filter and deconvolution applied. Reduction velocity $8.0 \mathrm{~km} / \mathrm{s}$. Polarization plots of arrivals indicated with arrows shown on the right hand side of the figure. Analysis time windows 5490-5640 ms (upper) and 8490-8640 ms (lower). Note the main particle motion in the vertical (upper) and horizontal (lower) plane, indicating a P- and S-wave respectively. The similar apparent velocities demonstrate that the S-wave has been P-to-S converted on the way up. 


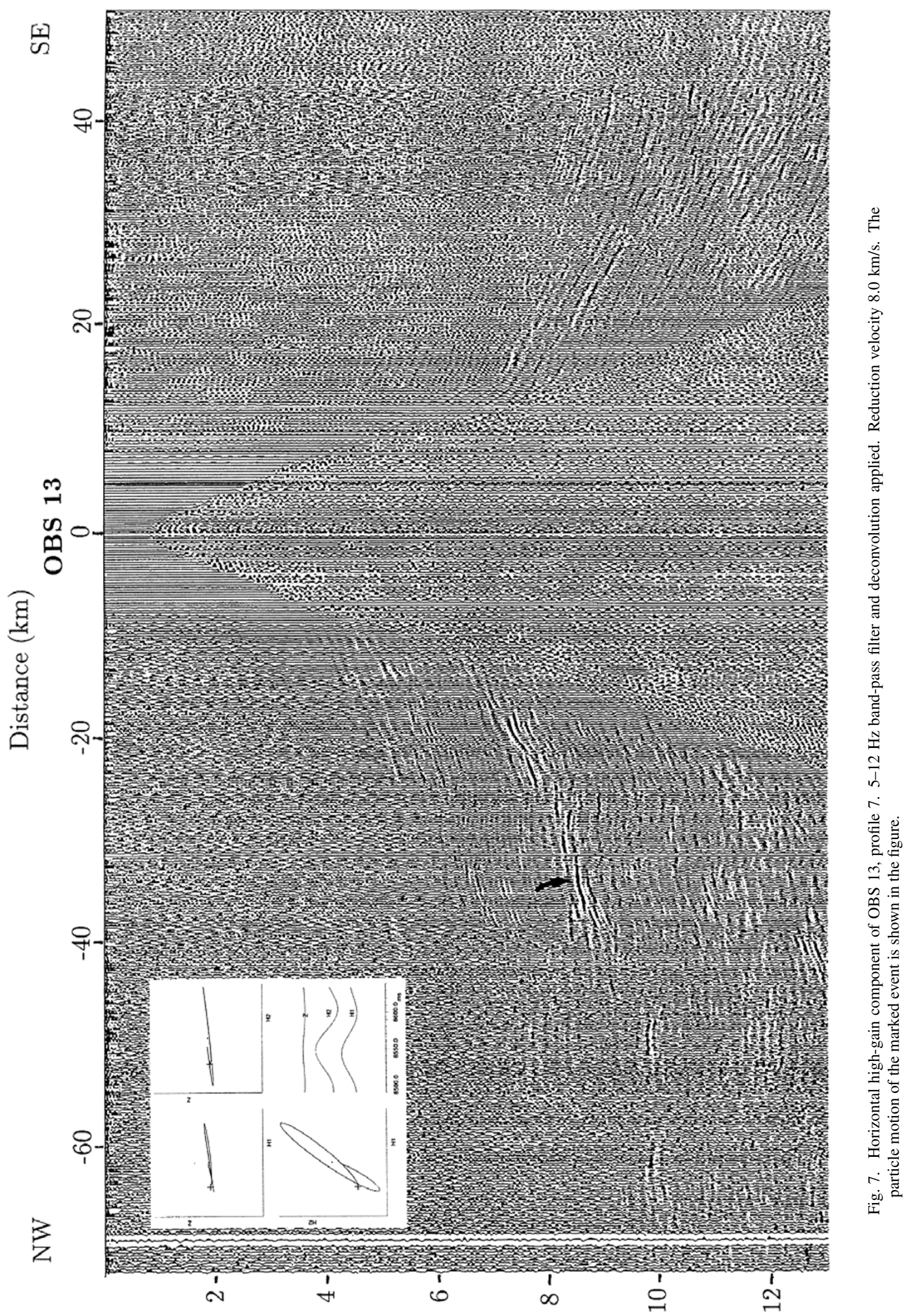

(วəs) 8/ब-匹 


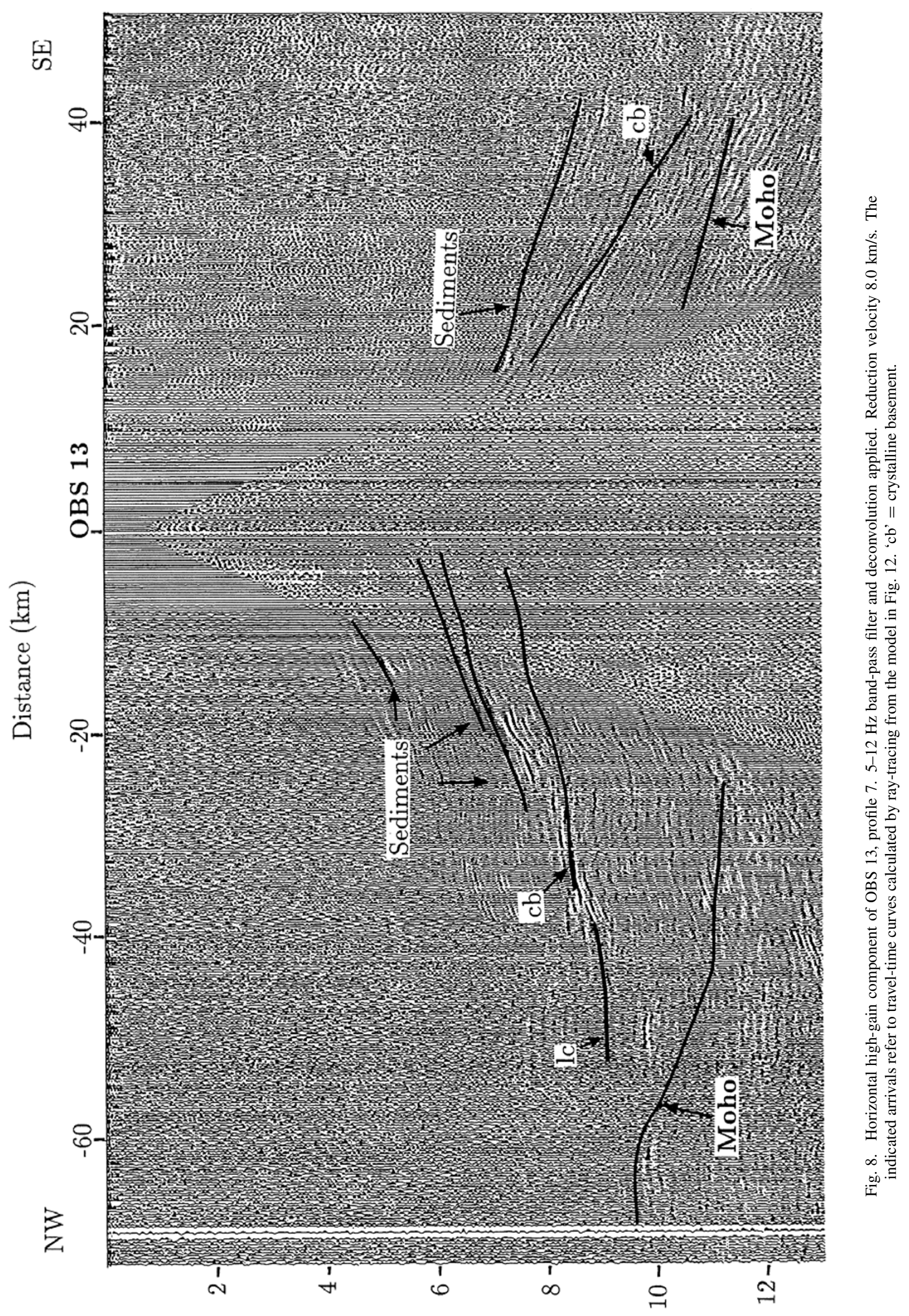

(วəs) 8/ள-L 


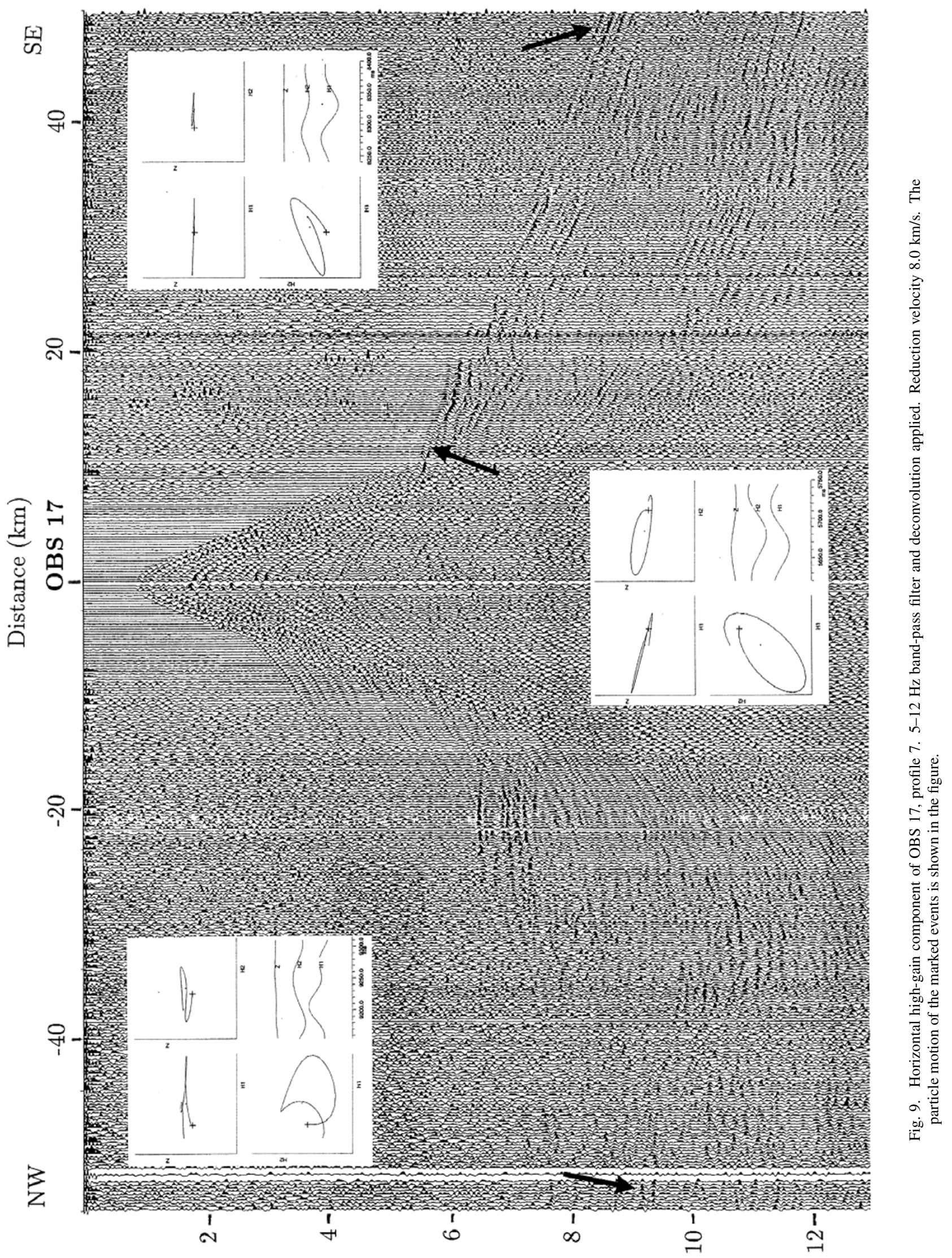

(วəs) $8 /$ đ-I 


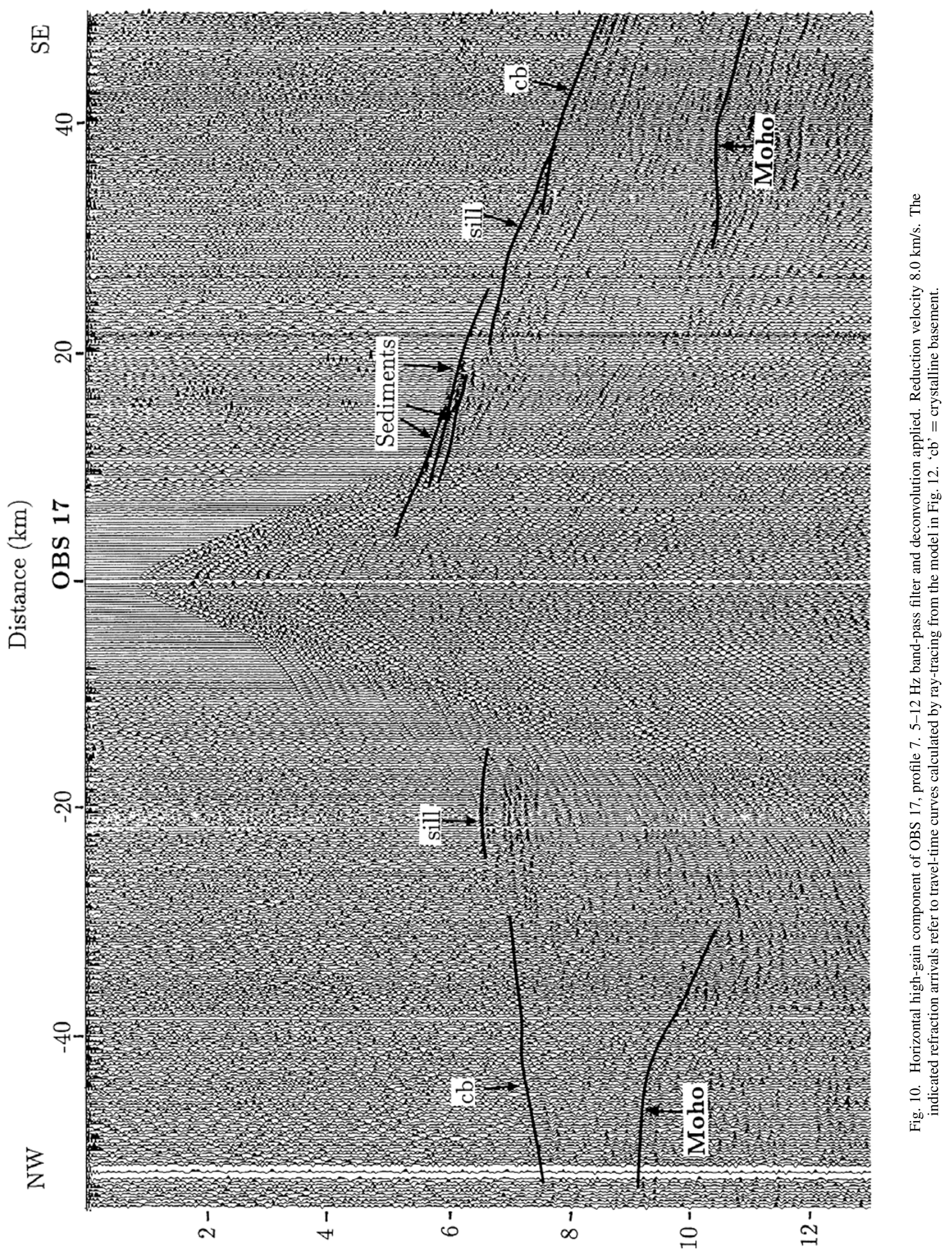

(วәs) 8/ब-エ 


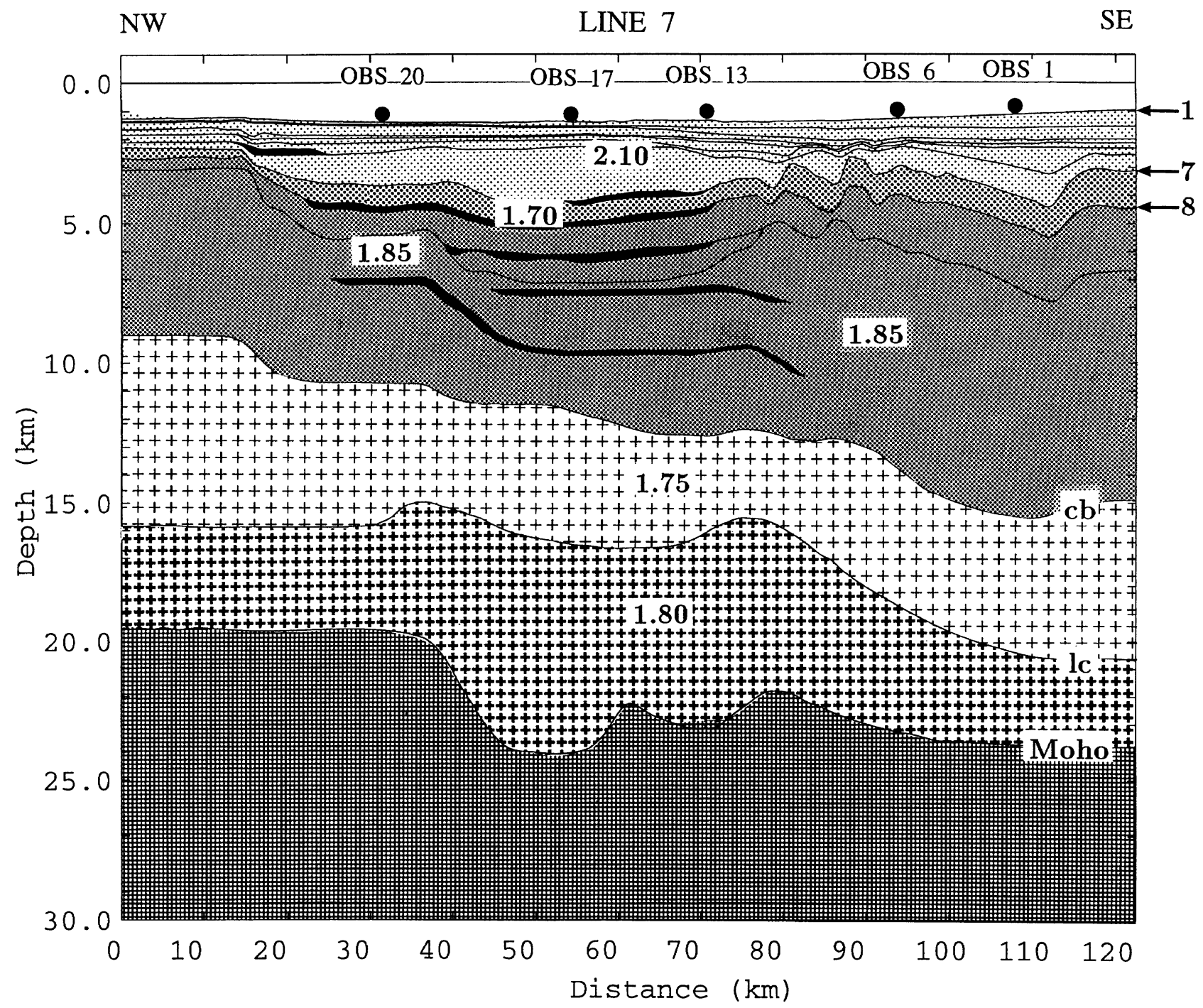

Fig. 11. The 2-D regional model for OBS profile 7 (Line 7, Fig. 2), with $V_{p} / V_{s}$ ratios indicated as bold numbers. The P- and shear-wave model geometry is identical. The black thin layers represent sills, the $V_{p} / V_{s}$ ratio in the sill intrusions are estimated to 1.75 . The numbers on the right hand side of the figure indicate interfaces discussed in the text. 'cb' = top of crystalline basement, 'lc' $=$ top of lower crust.

waves are orthogonally polarized, and in Fig. 6 hodograms of the marked events indicate typical particle motions for compressional- and shear-waves. Additional hodograms are shown in Figs. 7 and 9. A recent compilation by Mjelde et al. (2002a), including datasets from passive margins, continental platforms and oceanic crust, has confirmed the idenfication of the arrivals as shear-waves.

The quality of the horizontal components are generally good, with a decrease in data quality in the southeastern part of the profile (OBS 1-5). This southeastern deterioration is not observed on the vertical components (Mjelde et al., 1997b), and may possibly be related to the number of intrusions decreasing southeastwards, thus creating a less favourable environment for mode conversion.

\section{Modelling}

The OBS-data response has been modelled using 2D kinematic (travel-time) ray-tracing. Amplitude (dynamic) modelling has not been considered, as Mjelde et al. $(1997 \mathrm{a}, \mathrm{b})$ concluded that large uncertainties were involved in the amplitude modelling of the P-wave data. Two different ray-tracing programmes have been used; NORSAR2D (Hovland, 1994), and a programme developed at the University of Tokyo (Iwasaki, 1988).

In the modelling it was attempted to keep the maximum misfit between the observed and calculated travel-times below $200 \mathrm{~ms}$ for the P-wave modelling of the profile (Mjelde et al., 1997b). However, it should be emphasized that the misfit is generally less than $50 \mathrm{~ms}$. For some OBS positions the $\mathrm{P}$-wave model geometry cannot explain the observed shear-wave arrivals. The interfaces in the P-wave model is generally well constrained, but along some segments poor ray coverage increases the uncertainty. The difference in the $\mathrm{P}$ - and $\mathrm{S}$-wave raypaths, and thus some parts of the model mapping different segments of the interfaces, may explain the misfit in some locations.

The regional shear-wave velocity model of the profile (Fig. 11) (Digranes et al., 1998) was based on the regional P-wave model presented by Mjelde et al. (1997a). In the regional P- and shear-wave modelling the data from the verti- 


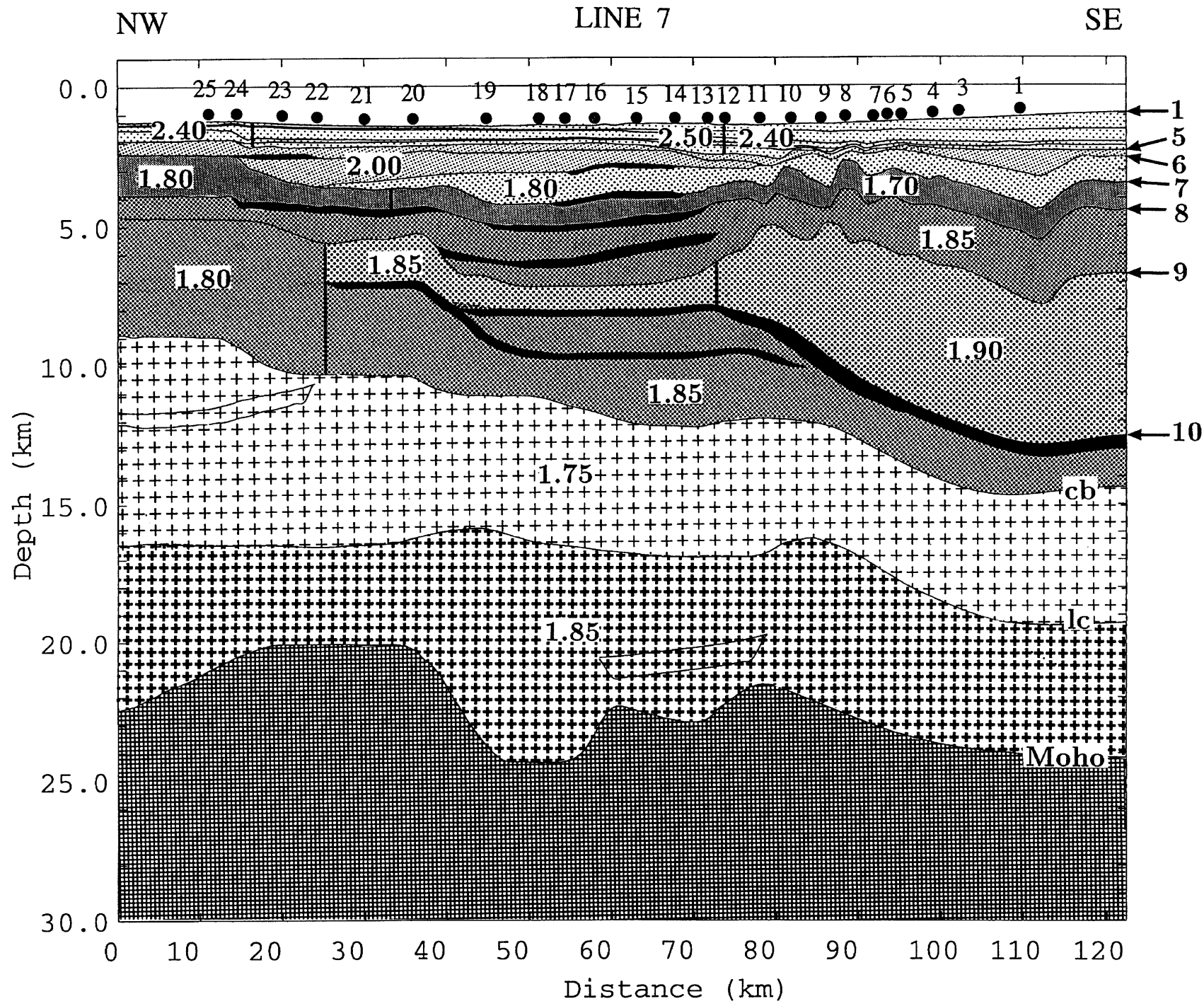

Fig. 12. The 2-D semi-regional model for OBS profile 7 (Line 7, Fig. 2), with $V_{p} / V_{s}$ ratios indicated as bold numbers. The P- and shear-wave model geometry is identical. The black thin layers represent sills, the $V_{p} / V_{s}$ ratio in the sill intrusions are estimated to 1.75 . The numbers on the right hand side of the figure indicate interfaces discussed in the text. Vertical black lines represent lateral changes in the $V_{p} / V_{s}$ ratio. 'cb' $=$ top of crystalline basement, 'lc' = top of lower crust.

$\mathrm{cal} /$ horizontal components from five of the twenty-five OBSs were analysed (OBS 1, 6, 13, 17, 20). Both in the regional and semi-regional shear-wave modelling we assume that the geometry and the P-wave velocity distribution is the same as for the corresponding P-wave model along the profile (Mjelde et al., 1996a, 1997b). The shear-wave velocities $\left(\mathrm{V}_{p} / \mathrm{V}_{s}\right.$ ratios) and conversion depths are then inferred from the ray-tracing modelling.

The band-pass filtered and deconvolved data from OBS 13 and 17 , as well as the data with calculated travel-time curves superimposed, are presented in Figs. 7-10. The regional and semi-regional shear-wave velocity models are presented in Figs. 11 and 12. The uncertainty in the compressional- and shear-wave velocities is estimated to be $\pm 0.1 \mathrm{~km} \mathrm{~s}^{-1}$, and the uncertainty in the $V_{p} / V_{s}$ ratio to be 0.05 (Mjelde and Sellevoll, 1993; Mjelde et al., 2002a).

\section{Discussion of Modelling Results \\ 6.1 $V_{p} / V_{s}$ and lithology}

The ratio between compressional- and shear-wave velocities $\left(V_{p} / V_{s}\right)$ is well established as an lithological indicator (e.g. Pickett, 1963; Domenico, 1984; Tatham, 1985; Tatham and McCormack, 1991). The low range of $V_{p} / V_{s}$ ratios (1.6-1.75) are associated with sandstones, limestones in the range from 1.84-1.99, while shales are associated with high values (1.70-3.0) (Domenico, 1984). However, variations in other rock parameters such as porosity, pore fluid, pore geometry and degree of consolidation will also affect the $V_{p} / V_{s}$ ratio (Tatham, 1982; Tatham and McCormack, 1991), and should be considered when a lithological interpretation is performed. High $V_{p} / V_{s}$ ratios in shallow marine sediments might be related to a low degree of compaction (e.g. Chung et al., 1990; Bromirski et al., 1992) while gas filled sandstones on the other hand can exhibit very low $(\leq 1.6)$ $V_{p} / V_{s}$ ratios (Tatham and McCormack, 1991). 


\subsection{P-wave models}

The geometry of the regional and semi-regional P-wave models (Mjelde et al., 1996b, 1997b) are shown in Figs. 11 and 12. The final models show that the semi-regional model is somewhat more detailed than the regional model, due to the much closer receiver spacing. The overall geometry and $\mathrm{P}$-wave velocity distribution of the two models are relatively similar, however, proving that the regional procedure with large OBS spacing provides a reliable regional model.

The distribution of sills in the two models are fairly similar, although the semi-regional model reveals more details, with an additional sill at about $2.5 \mathrm{~km}$ depth. The second lowermost sill is about $1 \mathrm{~km}$ deeper and extends further eastwards in the semi-regional model, in addition to being much thicker (locally more than $500 \mathrm{~m}$ ). The top of the crystalline crust has generally a very similar geometry in the two models. The Moho also has a similar appearence in the two models, and it must be underlined that the deepening of the Moho towards NW in the semi-regional model cannot be imaged by the OBS-data; it is included from isostatic considerations only. The deeper Moho structure to the NW has been confirmed by combined OBS and gravity modelling of more recent data acquired in that part of the area (Mjelde et al., 2001).

\subsection{Sediments and sills}

The main difference between the regional (Fig. 11) and semi-regional (Fig. 12) shear-wave velocity models is the improved vertical and lateral resolution in the semi-regional model, primarily in the upper 6-7 km. In the regional shearwave velocity model the uppermost sedimentary interface mapped by the shear waves is located at $3-4 \mathrm{~km}$ depth (interface 7 , Fig. 11). Thus, only the average $V_{p} / V_{s}$ ratio (2.1) in the interval above is inferred. In the semi-regional model (Fig. 12) denser spatial sampling allows the shallow sediments to be better resolved. Interface 5, 6 and 7 (Fig. 12) in the 1-4 $\mathrm{km}$ depth range are mapped by the shear waves, and $V_{p} / V_{s}$ ratios of $2.4 / 2.5,2.0$ and 1.8 are estimated in the corresponding intervals. The average $V_{p} / V_{s}$ ratio in the interval above interface 7 is $\approx 2.10-2.15$ in the semi-regional model, close to the $V_{p} / V_{s}$ ratio of 2.1 inferred for the same interval in the regional model.

The relatively high $V_{p} / V_{s}$ ratio (2.4/2.5) inferred for the uppermost layers (layer 2-5) in the semi-regional model is interpreted to reflect a very high $V_{p} / V_{s}$ ratio just below the sea bed due to poorly consolidated sediments, with $V_{p} / V_{s}$ decreasing with depth as the sediments become more consolidated. This is observed by several authors; Kodaira et al. (1996) found $V_{p} / V_{s}$ ratios of 3.0-5.5 in the shallow sediments on the Lofoten continental margin, Mjelde et al. (2002b) inferred $V_{p} / V_{s}$ ratios of 4.6-7 on the Vøring Plateau, and Chian and Louden (1994) obtained a $V_{p} / V_{s}$ ratio of 4.0 in the top of the sediments at the south-western Greenland margin. Furthermore, Castagna et al. (1985) obtained $V_{p} / V_{s}$ ratios as a function of depth for Gulf Coast shales and water-saturated sandstones, varying from 5.0 to 2.0 in the $0-1.5 \mathrm{~km}$ depth range. The decrease in $V_{p} / V_{s}$ ratio to 2.0 and 1.8 between interface 5-6 and 6-7, respectively (Fig. 12, 2-4 km depth) is probably related to increased compaction of the sediments, and possibly also to a change in lithology.
Interface 7 and 8 is well resolved both in the regional and the semi-regional model, and the $V_{p} / V_{s}$ ratio in this interval is estimated to 1.7 in both models, with an increase to 1.8 in the northwestern part of the semi-regional model. Interface number 8 (Figs. 11 and 12) has been interpreted as middle Cenomanian on the basement highs, based on correlation with boreholes on the continental shelf (e.g. Dalland et al., 1988). The change in lithology indicated by the low $V_{p} / V_{s}$ ratio might thus imply a higher sand content in the mid-Cretaceous sediments, with a northwestward decrease in the sand content indicated in the semi-regional model. The dating of the interfaces and higher sand content in the midCretaceous have been confirmed by a recent drillhole on the structure beneath OBS 6 (Norwegian Petroleum Directorate, unpublished).

In the regional model a $V_{p} / V_{s}$ ratio of 1.85 is estimated in the interval between the second uppermost sill and the crystalline basement. A somewhat more detailed shear-wave velocity model in the same interval is inferred from the semiregional modelling. The $V_{p} / V_{s}$ ratios varies from 1.85 to 1.9 and back to 1.85 in the southeastern part of the profile, and a north-westward decrease in the $V_{p} / V_{s}$ ratio is observed at $\approx 7-8 \mathrm{~km}$ depth (Fig. 12). The level of the base Cretaceous reflector is a matter of dispute (Blystad et al., 1995), and we infer these sediments to be of pre-Cretaceous and early Cretaceous age without a more detailed subdivision. Thus the expected main lithological units are: late Permian carbonates, clastic sediments of Triassic age, predominance of sandstones in the Jurassic and earliest Cretaceous marine shales (Doré, 1991; Larsen, 1987; Skogseid et al., 1992). The $V_{p} / V_{s}$ ratios inferred from the semi-regional modelling indicates both lateral and vertical variations in lithology, and the range of $V_{p} / V_{s}$ ratios (1.80-1.90) is consistent with the expected sedimentary units. However, one must consider the possibility that the resolved intervals cover several lithological units, and we feel that a more detailed lithological interpretation would be speculative.

The sill intrusions in the $3-10 \mathrm{~km}$ depth range are generally well mapped by the shear waves in both the regional and semi-regional modelling. Mode conversions are modelled to occur primarily at these high velocity interfaces, and the $V_{p} / V_{s}$ ratio in the sill intrusions are estimated to 1.75 . This corresponds well with values obtained from ODP drillhole 642 (Fig. 1) on the outer Vøring Margin (Barton et al., 1989).

\subsection{Crystalline basement, lower crust and the Moho}

The top of the crystalline basement is defined as the deepest $6.2 \mathrm{~km} / \mathrm{s}$ refraction arrival in the $\mathrm{P}$-wave modelling, and the $\mathrm{P}$-wave velocity of the upper and middle crystalline crust $(6.2-6.6 \mathrm{~km} / \mathrm{s})$ confirms that the crust is of continental origin (Mjelde et al., 1997a).

The crystalline basement is clearly mapped by the shear waves in both the regional and semi-regional modelling, and both models indicate a $V_{p} / V_{s}$ ratio of 1.75 in the upper and middle crust (Figs. 11 and 12). This compares well with values obtained for the crystalline basement further north in the Lofoten area (Mjelde and Sellevoll, 1993). It is also close to the $V_{p} / V_{s}$ ratio (1.73-1.77) considered to be typical for the continental crust (Holbrook et al., 1992; Christensen, 1996), and supports the conclusion from the P-wave modelling that 
the crust in the Vøring Basin is of continental origin.

The regional modelling maps the Moho and segments of the lower crust, and indicates an increase in the $V_{p} / V_{s}$ ratio from 1.75 in the upper/middle crust to 1.80 in the lower crust. This increase is confirmed by the semi-regional modelling where both the lower crust and the Moho are clearly mapped, and a $V_{p} / V_{s}$ ratio of 1.85 is inferred for the lower crust. Thus the denser OBS spacing in the semi-regional experiment enables a more precise estimate on the lower crustal shear-wave velocities. This is important as the $V_{p} / V_{s}$ ratio of 1.85 is indicative of the composition of the lower crust.

Laboratory measurements of $V_{p}$ and $V_{s}$ in oceanic basalts (Hamilton, 1979) indicated $V_{p} / V_{s}$ ratios between 1.86 and 2.04. Corresponding measurements on gabbro gave $V_{p} / V_{s}$ ratios between 1.77 and 1.90 (Holbrook et al., 1992) and 1.85-1.86 (Christensen, 1996). In-situ measurements in the oceanic crust of the Lofoten margin (Kodaira et al., 1996) revealed $V_{p} / V_{s}$ ratios of $1.86,1.76$ and 1.80 for the upper, middle and lower crust respectively, while Mjelde et al. (1996b) estimated a mean $V_{p} / V_{s}$ ratio of 1.9 for the entire crust immediately seaward of the continent-ocean transition in the same area. In a study from the continent-ocean transition across the southwest Greenland margin Chian and Louden (1994) inferred a $V_{p} / V_{s}$ ratio of 1.88 in the lower crust.

The lower crust in the Vøring area is by many authors interpreted as a magmatic underplated body formed prior to the opening between Norway and Greenland under the influence of the Iceland hotspot (e.g. Skogseid et al., 1992; Eldholm and Grue, 1994). Mjelde et al. (1996c) interpreted a landward P-velocity decrease in the lower crust as a gradual landward decrease in the amount of high-velocity 'oceanic' intrusions into the stretched continental crust of the Lofoten margin. The $V_{p} / V_{s}$ ratio inferred for the lower crust along the OBS profile in the Vøring Basin (1.80-1.85) falls within the lower range of gabbro (e.g. Holbrook et al., 1992; Christensen, 1996). A 'mixing' of continental crust and 'oceanic' intrusions as suggested by Mjelde et al. (1996c) could thus explain the $V_{p} / V_{s}$ ratio inferred for the lower crust, and would also support the 'hot-spot' hypothesis.

\section{Summary and Conclusions}

Semi-regional OBS data have been acquired on 25 OBSs deployed along a $120 \mathrm{~km}$ long profile in the Vøring Basin. Utilizing an established semi-regional P-wave model the shear waves recorded on the horizontal components have been modelled by use of 2-D kinematic ray-tracing. The semi-regional shear-wave velocity model is compared with a regional model derived from 5 OBSs along the same profile, and the final models show that the lateral and vertical resolution in the semi-regional model is improved due to the closer receiver spacing. The average shear-wave velocity distribution of the two models is fairly similar, however, and the differences between the two models are within the range of errors estimated for the regional model, indicating that the regional procedure with large OBS spacing provides a reliable regional model.

The main difference between the regional and semiregional shear-wave velocity models is the improved resolution in the upper 6-7 km in the semi-regional model. The models indicate that increasing the receiver density by a fac- tor of 5, doubles the vertical and horizontal resolution within this interval. The shallow sediments are better resolved due to the denser spatial sampling, and the estimated decrease in the $V_{p} / V_{s}$ ratio in the $1-4 \mathrm{~km}$ depth range from $2.4 / 2.5$ to 1.8 is interpreted to mainly reflect the increased compaction of the sediments with increasing depth.

At $\approx 4 \mathrm{~km}$ depth a decrease in the $V_{p} / V_{s}$ ratio to 1.70 is observed both in the regional and semi-regional model, with an northwestward increase to 1.80 in the semi-regional model. The low $V_{p} / V_{s}$ ratio suggests a change in lithology to more sand-rich sediments in this interval, which is interpreted as mid-Cretaceous based on correlations with boreholes.

An average $V_{p} / V_{s}$ ratio of 1.85 is estimated for the interval between the second uppermost sill and the crystalline basement in the regional model. These sediment are interpreted to be of pre-Cretaceous and early Cretaceous age, and the inferred $V_{p} / V_{s}$ ratio is consistent with the expected sand/shale and sand/clastics/limestone lithologies. The same interval is better resolved in the semi-regional modelling, and $V_{p} / V_{s}$ ratios varying from $1.80-1.90$ indicates both lateral and vertical variations in the lithology.

The upper and middle crust are clearly mapped both in the regional and semi-regional model, and the inferred $V_{p} / V_{s}$ ratio of 1.75 is considered to be typical for the continental crust. In the lower crust an increase in the $V_{p} / V_{s}$ ratio is observed, to 1.80 and 1.85 in the regional and semi-regional models, respectively. This indicates a more mafic composition in the lower crust, supporting the interpretation that the lower crust is a "mixing" of continental crust and magmatic underplating formed prior to the opening between Norway and Greenland.

Acknowledgments. Prof. M. A. Sellevoll at IFJ is greatly acknowledged for his support during the planning of the experiment, and for comments on the manuscript. We thank Statoil for the permission to present these results, and for economic support. The paper was significantly improved by critical comments from Robert $\mathrm{H}$. Tatham and one anonymous referee.

\section{References}

Asada, T., T. Kanazawa, and H. Shimamura, A pop-up type ocean bottom seismograph, Prog. Abstr. Seism. Soc. Japan, 114, 1979 (in Japanese).

Barton, C., D. Moos, and J.-P. Blangy, Analysis of full waveform acoustic logging data at ODP site 642 - outer Vøring Plateau, in Proc. ODP, Sci. Results, 104, edited by O. Eldholm, J. Thiede, and J. Taylor, College Station, TX (Ocean Drilling Program), pp. 953-964, 1989.

Berndt, C., O. P. Skogly, S. Planke, O. Eldholm, and R. Mjelde, Highvelocity breakup-related sills in the Vøring Basin, off Norway, J. Geophys. Res., 105, 28443-28454, 2000.

Blystad, P., H. Brekke, R. B. Færseth, B. T. Larsen, J. Skogseid, and B. Tørudbakken, Structural elements of the Norwegian continental shelf. Part 2: The Norwegian Sea Region, NPD Bull., 8, (Norwegian Petroleum Directorate), 1995.

Bromirski, P. D., L. N. Frazer, and F. K. Dunnebier, Sediment shear Q from airgun OBS data, Geophys. J. Int., 110, 465-485, 1992.

Bøen, F., S. Eggen, and J. Vollset, Structures and basins of the margin from $62-69^{\circ} \mathrm{N}$ and their development, in Petroleum Geology of the North European Margin, edited by A. M. Spencer, et al., pp. 3-28, Graham and Trotman, London, 1984

Castagna, J. P., M. L. Batzle, and R. L. Eastwood, Relationships between compressional wave and shear wave velocities in clastic silicate rocks, Geophysics, 50, 571-581, 1985.

Chian, D. and K. E. Louden, The continent-ocean crustal transition across the southwest Greenland margin, J. Geophys. Res., 99, 9117-9135, 1994. Christensen, N. I., Poisson's ratio and crustal seismology, J. Geophys. Res., 
101, 3139-3156, 1996

Chung, T. W., N. Hirata, and R. Sato, Two-dimensional P- and S-wave velocity structure of the Yamato Basin, the southern Japan sea, from refraction data collected by an ocean bottom seismographic array, J. Phys. Earth, 38, 99-147, 1990.

Dalland, A., D. Worsley, and K. Ofstad, A lithostratigraphic scheme for the Mesozoic and Cenozoic succesion offshore Norway north of $62^{\circ} \mathrm{N}$, Norw. Petrol. Dir. Bull. No (ISBN 82-7275-241-9), 67 pp., 1988.

Digranes, P., R. Mjelde, S. Kodaira, H. Shimamura, T. Kanazawa, H. Shiobara, and E. W. Berg, Modelling shear waves in OBS data from the Vøring Basin (northern Norway) by 2-D ray-tracing, PAGEOPH, 4, 611629, 1996.

Digranes, P., R. Mjelde, S. Kodaira, H. Shimamura, T. Kanazawa, H. Shiobara, and E. W. Berg, A regional shear-wave velocity model in the central Vøring Basin, N. Norway, using three-component Ocean Bottom Seismographs, Tectonophys., 293, 157-174, 1998.

Domenico, S. N., Rock lithology and porosity determination from shear and compressional wave velocity, Geophysics, 49, 1188-1195, 1984.

Doré, A. G., The structural foundation and evolution of Mesozoic seaways between Europe and the Arctic, Pal. Pal. Pal., 87, 441-492, 1991.

Eldholm, O. and K. Grue, North Atlantic volcanic margins: Dimensions and production rates, J. Geophys. Res., 99, 2955-2968, 1994.

Eldholm, O. and J. C. Mutter, Basin structure of the Norwegian Margin from analysis of digitally recorded sonobuoys, J. Geophys. Res., 91, 3763 3783,1986

Eldholm, O., J. Thiede, and E. Taylor, Evolution of the Norwegian Continental Margin: Background and Objectives, in Init. Reports (Pt. A), ODP, 104, edited by O. Eldholm, J. Thiede, and E. Taylor, pp. 5-25, 1987.

Eldholm, O., J. Thiede, and E. Taylor, Evolution of the Vøring Volcanic Margin, in Proc. ODP, Sci. Results, 104, edited by O. Eldholm, J. Thiede, and E. Taylor, College Station, TX (Ocean Drilling Program), pp. 1033 $1065,1989$.

Eldholm, O., J. Skogseid, E. Sundvor, and A. M. Myhre, The NorwegianGreenland Sea, in The Geology of North America, vol. L, The Arctic Ocean Region, The Geological Society of America, pp. 351-363, 1990.

Hamilton, E. L., Shear Wave Velocity Versus Depth in Marine Sediments: A Review, Geophysics, 41, 985-996, 1976

Hamilton, E. L., $V_{p} / V_{s}$ and Poisson's ratio in marine sediments and rocks, J. Acoust. Soc. Am., 66, 1093-1101, 1979.

Holbrook, W. S., W. D. Mooney, and N. J. Christensen, The seismic veloc ity structure of the deep continental crust, in Continental Lower Crust, edited by D. M. Fountain, R. Arculus, and R. W. Kay, Development in Geotectonics 23, Elsevier, Amsterdam, pp. 1-43, 1992.

Holbrook, W. S., E. C. Reiter, G. M. Purdy, D. Sawyer, P. L. Stoffa, J. A Austin, J. Oh, and J. Makris, Deep structure of the U.S. Atlantic continental margin, offshore South Carolina, from coincident ocean bottom and multichannel seismic data, J. Geophys. Res., 99, 9155-9178, 1994.

Hovland, H., Norsar 2D Ray modelling version 3.0, User's manual, Norsar, Kjeller, 1994.

Iwasaki, T., Ray-tracing program for study of velocity structure by ocean bottom profiling, Zisin, 41, 263-266, 1988 (in Japanese).

Kanazawa, T., A seven component, a low power consumption and an acoustic comandable ocean bottom seismograph, Prog. Abstr. Seism. Soc. Japan, 2, 240, 1986 (in Japanese).

Kanazawa, T., Technical Description of TK92-type ocean bottom seismometer, Investigation of the central and northern part of the Vøring Basin by use of Ocean Bottom Seismographs, R/V Håkon Mosby 22 aug.-24 sept. 1992, cruise report, Mjelde, R., 1993.

Kennett, B. L. N., How does the shear-wave structure of the seabed affect the seismic wavefield?, Geophys. J. Int., 124, 341-348, 1996.

Kim, N. W. and A. J. Seriff, Marine PSSP reflections with a bottom velocity transition Zone, Geophysics, 57, 161-170, 1992.

Kodaira, S., M. Bellenberg, T. Iwasaki, T. Kanasawa, H. B. Hirschleber, and $\mathrm{H}$. Shimamura, $V_{p} / V_{s}$ ratio structure of the Lofoten continental margin, northern Norway, and its geological implications, Geophys. J. Int., 124 724-740, 1996.

Larsen, V. B., A synthesis of tectonically-related stratigraphy in the North Atlantic-Arctic region from Aalenian to Cenomanian time, Norsk Geologisk Tidsskrift, 67, 281-293, 1987.

Larsen, B. T., R. Krigsvoll, and O. R. Heum, Structural style and tectonic development of the Haltenbanken area, Mid-Norway, (abstract), Norwegian Petrol. Soc. conf. on structural and tectonic modelling and its application to petroleum geology, Stavanger, 18-20 October 1989, 1989.

Mjelde, R. and M. A. Sellevoll, Possible shallow crustal S-wave anisotropy off Lofoten, Norway, inferred from 3-C Ocean Bottom Seismographs,
Geophys. J. Int., 115, 159-167, 1993.

Mjelde, R., A. Strøm, E. W. Berg, H. Shimamura, T. Kanazawa, H. Shiobara, S. Kodaira, and J. P. Fjellanger, Investigation of the central and northern part of the Vøring Basin by use of Ocean Bottom Seismographs, R/V Håkon Mosby 22 aug.-24 sept. 1992, Cruise report, Statoil, 1993.

Mjelde, R., E. W. Berg, A. Strøm, O. Riise, H. Shimamura, T. Kanazawa H. Shiobara, S. Kodaira, and J. P. Fjellanger, An extensive Ocean Bottom Seismograph survey in the Vøring Basin, N. Norway, First Break, 14 247-256, 1996a.

Mjelde, R., B. Myhre, M. A. Sellevoll, H. Shimamura, T. Iwasaki, and T. Kanazawa, Modelling of S-waves from an area covered with flood-basalts off Lofoten, N. Norway, Geoph. Trans., 40(1), 95-117, 1996b.

Mjelde, R., S. Kodaira, R. K. Hassan, A. Goldschmidt-Rokita, N. Tomita M. A. Sellevoll, H. B. Hirschleber, H. Shimamura, T. Iwasaki, and T. Kanazawa, The continental/ocean transition of the Lofoten volcanic margin, N. Norway, J. Geodynam., 22, 189-206, 1996c.

Mjelde, R., S. Kodaira, H. Shimamura, T. Kanazawa, H. Shiobara, E. W. Berg, and O. Riise, Crustal structure of the central part of the Vøring Basin, N. Norway, from three-component Ocean Bottom Seismographs, Tectonophys., 277, 235-257, 1997a.

Mjelde, R., S. Kodaira, P. Digranes, H. Shimamura, T. Kanazawa, H. Shiobara, E. W. Berg, and O. Riise, Comparison between a regional and semi-regional crustal OBS-model in the Vøring Basin, N. Norway, PAGEOPH, 149, 641-665, 1997b.

Mjelde, R., P. Digranes, H. Shimamura, H. Shiobara, S. Kodaira, H. Brekke, T. Egebjerg, N. Sørenes, and T. Thorbjørnsen, Crustal structure of the northern part of the Vøring Basin, mid-Norway margin, from wide-angle seismic and gravity data, Tectonophys., 293, 175-205, 1998.

Mjelde, R., P. Digranes, M. Van Schaack, H. Shimamura, H. Shiobara, S Kodaira, O. Næss, N. Sørenes, and E. Vågnes, Crustal structure of the outer Vøring Plateau, offshore Norway, from ocean bottom seismic and gravity data, J. Geophys. Res., 106, 6769-6791, 2001.

Mjelde, R., J. P. Fjellanger, T. Raum, P. Digranes, S. Kodaira, A. Breivik, and H. Shimamura, Where do P-S converions occur? Analysis of OBSdata from the NE Atlantic Margin, First Break, 2002a (in press).

Mjelde, R., T. Raum, P. Digranes, H. Shimamura, H. Shiobara, and S. Kodaira, S-wave structure of the Vøring Margin, mid-Norway margin, from OBS-data, Tectonophys., 2002b (submitted).

Morgan, J. V., P. J. Barton, and R. S. White, The Hatton Bank continental margin, III, Structure from wide-angle OBS and multichannel seismic refraction profiles, Geophys. J. Int., 98, 367-384, 1989.

Mutter, J. C., M. Talwani, and P. L. Stoffa, Evidence for a thick oceanic crust adjacent to the Norwegian margin, J. Geophys. Res., 89, 483-502, 1984.

Mutter, J. C., W. R. Buck, and C. M. Zehnder, Convective partial melting. 1. A model for the formation of thick basaltic sequences during the initiation of spreading, J. Geophys. Res., 93, 1031-1048, 1988

Pickett, G. R., Acoustic character logs and their application in formation evaluation, J. Pet. Tech., 659-667, 1963.

Planke, S., J. Skogseid, and O. Eldholm, Crustal structure off Norway, 6270 N, Tectonophys., 189, 91-107, 1991.

Raum, T., R. Mjelde, P. Digranes, H. Shimamura, H. Shiobara, S. Kodaira, G. Haatvedt, N. Sørenes, and T. Thorbjørnsen, Crustal structure of the southern part of the Vøring basin, mid-Norway margin, from wide-angle seismic and gravity data, Tectonophys., 2002 (in press).

Samson, C., P. J. Barton, and J. Karwatowski, Imaging beneath an opaque basaltic layer using densly sampled wide-angle OBS data, Geophys. Prosp., 43, 509-528, 1995

Shimamura, H., OBS technical description, Annexe to cruise report, Sellevoll, 1988, Inst. of Solid Earth Physics, Univ. of Bergen, 52 pp., 1988.

Skogseid, J. and O. Eldholm, Vøring Plateau Continental Margin: Seismic interpretation, stratigraphy and vertical movements, in Proc. ODP, Sci. Results, 104, edited by O. Eldholm, J. Thiede, and J. Taylor, College Station, TX (Ocean Drilling Program), 1989.

Skogseid, J., T. Pedersen, O. Eldholm, and B. T. Larsen, Tectonism and Magmatism during NE Atlantic continental break-up: the Vøring margin, in Magmatism and the Causes of Continental Break-up, edited by B C. Story, T. Alabaster, and R. J. Plankhurst, Geological Society Special Publications, 68, pp. 305-320, 1992.

Spencer, A. M. et al. (Eds.), Petroleum Geology of the North European Margin, pp. 436, London, Graham and Trotman, 1984.

Spencer, A. M. et al. (Eds.), Habitat of Hydrocarbons on the Norwegian continental shelf, Graham and Trotman, London, 1986.

Surlyk, F., S. Piasecki, F. Rolle, L. Stemmerik, E. Thomsen, and P. Wrang, The Permian basin of East Greenland, in Petroleum Geology of the North 
European Margin, edited by A. M. Spencer et al., pp. 303-315, Graham and Trotman, London, 1984.

Talwani, M., G. Udintsev, et al. (Eds.), Tectonic synthesis, in Initial reports Deep Sea Drilling Project. 38, Washington, D.C., U.S. Government Printing Office, pp. 1213-1242, 1976.

Tatham, R. H., $V_{p} / V_{s}$ and lithology, Geophysics, 47, 336-344, 1982.

Tatham, R. H., Shear waves and lithology, in Seismic Shear Waves, Part B: Applications, edited by G. Dohr, pp. 86-133, Geophysical Press, London-Amsterdam, 1985.

Tatham, R. H. and D. V. Goolsbee, Separation of S-wave and P-wave reflections offshore western Florida, Geophysics, 49, 493-508, 1984.

Tatham, R. H. and M. D. McCormack, Rock Physics Measurements, in Multicomponent Seismology in Petroleum Exploration, edited by E. B.
Neitzel and D. F. Winterstein, SEG Investigation in Geophysics Series, 6, pp. 43-91, 1991.

Todd, B. J. and I. Reid, The continent-ocean boundary south of Flemish Cap: constraints from seismic refraction and gravity, Can. J. Earth Sci., 26, 1392-1407, 1989.

White, R. S. and R. A. Stephen, Compressional to shear wave conversion in oceanic crust, Geophys. J. R. astr. Soc., 63, 547-565, 1980.

Yamada, T., T. Asada, and H. Shimamura, A pop-up ocean bottom seismograph, Prog. Abst. Seism. Soc. Japan, 2, 126, 1981 (in Japanese).

P. Digranes, R. Mjelde (e-mail: rolf.mjelde@ifjf.uib.no), S. Kodaira, H. Shimamura, T. Kanazawa, and H. Shiobara 